\title{
The Relationship Between Smartphone Use in the Lavatory and Hemorrhoidal Disease
}

\section{Lavaboda Akıllı Telefon Kullanımı ile Hemoroidal Hastalık Arasındaki İlişki}

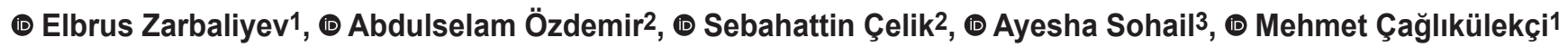 \\ ${ }^{1}$ Yeni Yüzyıl University Faculty of Medicine, Department of General Surgery, İstanbul, Turkey \\ 2Van Yüzüncü Yıl University Faculty of Medicine, Department of General Surgery, Van, Turkey \\ ${ }^{3}$ Mathematics Comsats University Islamabad, Islamabad, Pakistan
}

\section{HIIIIII| ABSTRACT}

Aim: Hemorrhoidal disease is a proctological problem that affects a large portion of the population at some point. Nowadays, excessive use of smartphones combined with evolving social media habits has resulted in the smartphone being used in the lavatory.

Method: The study group consisted of patients admitted to the general surgery outpatient clinic with hemorrhoids, and the control group consisted of healthy volunteers with no such complaints. All participants were given a questionnaire with questions about their smartphone usage habits. The degree of hemorrhoidal disease, if any, was determined by an experienced general surgeon who performed the physical examinations.

Results: The study group had 882 participants and the control group had 802. While 64.7\% (571) patients of the former took their smartphones with them to the lavatory, only $38.4 \%$ (308) participants of the control group did ( $\mathrm{p}<0.001$ ). Of the study group, $49.9 \%$ actually used their smartphones while in the lavatory, whereas only $27.3 \%$ of the control group did $(\mathrm{p}<0.001)$. For every additional minute spent using a smartphone in the lavatory, the likelihood of being in the hemorrhoid group increased by 1.26 times (95\% confidence interval $=1.162-1.364$ ).

Conclusion: Smartphones are now commonly used even in the lavatory, and this habit may be a risk factor for hemorrhoids. Therefore, to treat hemorrhoids, it is advisable for patients to abandon this habit.

Keywords: Hemorrhoidal disease, risk factors, smartphone

\section{|HIIIII|| ÖZ}

Amaç: Hemoroidal hastalık, nüfusun önemli bir bölümünün bir noktada karşılaştığı proktolojik bir sorundur. Günümüzde, cep telefonlarının aşırı sosyal medya alışkanlıkları ile birlikte aşırı kullanımı, birincisinin tuvalette kullanılmasına yol açmıştır. Bu çalışmanın amacı, lavaboda cep telefonu kullanımının hemoroidal hastalık ile ilişkili olup olmadığını araştırmaktır.

Yöntem: Genel cerrahi polikliniğine hemoroid şikayeti ile başvuran hastalar çalışma grubuna dahil edilirken, bu tür şikayeti olmayan sağlıklı gönüllüler kontrol grubunu oluşturdu. Tüm katılımcılara cep telefonu kullanım alışkanlıkları hakkında sorular içeren bir anket verildi. Hemoroid hastalığının derecesi, varsa, fizik muayeneleri bizzat yapan deneyimli bir genel cerrah tarafından belirlendi.

Bulgular: Çalışma grubu 882 katılımcı ve 802 kontrol grubundan oluşmaktaydı. Birincisinin \%64,7'si (571 hasta) yanlarında cep telefonlarını lavaboya götürürken, bu oran kontrol grubu için sadece \%38,4 (308 hasta) idi ( $\mathrm{p}<0,001$ ). Çalışma grubunun \%49,9'u tuvaletteyken cep telefonlarında zaman geçirirken, kontrol grubunun sadece \%27,3'ü bunu yapmıştı $(\mathrm{p}<0,001)$. Lavaboda bir cep telefonu kullanılarak geçirilen her ilave dakika için, hemoroit grubunda olma olasılığının 1,26 kat arttığı belirlendi (\%95 güven aralığı =1,162-1,364).

Sonuç: Cep telefonları artık lavaboda bile yaygın olarak kullanılmaktadır, bu alışkanlık hemoroit için risk faktörü olabilir. Bu nedenle, hemoroid tedavisi için, hastaların bu alışkanlı̆̆ı bırakmaları tavsiye edilebilir.

Anahtar Kelimeler: Hemoroidal hastalık, risk faktörleri, akıllı telefon 


\section{Introduction}

Hemorrhoidal disease is a common condition seen in general surgery polyclinics. ${ }^{1}$ Currently, $45 \%-50 \%$ of the population has complained of hemorrhoidal disease at some point in their lives. ${ }^{2}$ According to previous studies, the prevalence of hemorrhoids ranges from $4.4 \%$ to $36 \%{ }^{3,4}$ This variation could be attributed to differences in the populations studied as well as differences in the diagnosis criteria used.

Despite numerous studies on the etiology and development mechanisms of hemorrhoidal disease, no consensus has been reached. Although it was previously thought that the expansion of varicosity in the venous blood vessels around the anus and an increase in pressure in the portal system influenced the development of hemorrhoidal disease, subsequent studies have indicated otherwise., ${ }^{5,6}$ More recently, inflammation has been linked to the development of hemorrhoidal disease. ${ }^{7}$ Increased pressure in the anal region leads to prolapsed hemorrhoids and also inhibits venous return. ${ }^{8}$ Obstructed venous return further worsens hemorrhoid prolapse and makes it symptomatic. ${ }^{9}$ Constipation was previously widely recognized as an important factor, but recent studies have indicated that diarrhea is more influential ${ }^{3}$. Although alcohol consumption along with consumption of spicy foods and low-fiber diet has not been shown to play a significant role in the etiology of hemorrhoidal disease, it is believed that strain during defecation aids in its development over time., ${ }^{5,10}$

Considering the accelerating factors in the development of hemorrhoids, the prevalence of the disease may be reasonably expected to be elevated in modern society. People now lead more sedentary lives than in the past eras, and they generally prefer high-calorie/high-fat low-fiber foods. In addition, smartphones have permeated every aspect of our daily lives. A number of studies have concluded that this situation has become a public health issue. ${ }^{11}$

Based on our clinical observations, we discovered that the use of smartphones in the lavatory, which is a fairly common occurrence in everyday life, has become a habit for some people. We believe that this habit, which results in long periods spent in the lavatory, will lead to an increase in the duration of straining and pressure in the anal region. However, there is a gap in the literature as we found no study investigating the relationship between the use of smartphones in the lavatory and the development of hemorrhoids. The goal of this study was to investigate the relationship between smartphone usage habits in the lavatory and hemorrhoidal disease.

\section{Materials and Methods}

\section{Study Design/Setting}

After receiving approval from the ethics committee of Yeni Yüzyıl University (İstanbul, Turkey), the study was carried out in collaboration with Van Yüzüncü Yıl University (Van, Turkey). The study was planned with a case-control design based on retrospective observations.

\section{Participants and Variables}

The study included patients admitted to the general surgery department with hemorrhoidal complaints between November 1, 2017, and May 31, 2018, as well as a control group of healthy volunteers with no hemorrhoidal complaints (Figure 1). The control group for the study was formed outside the target population. Care was taken

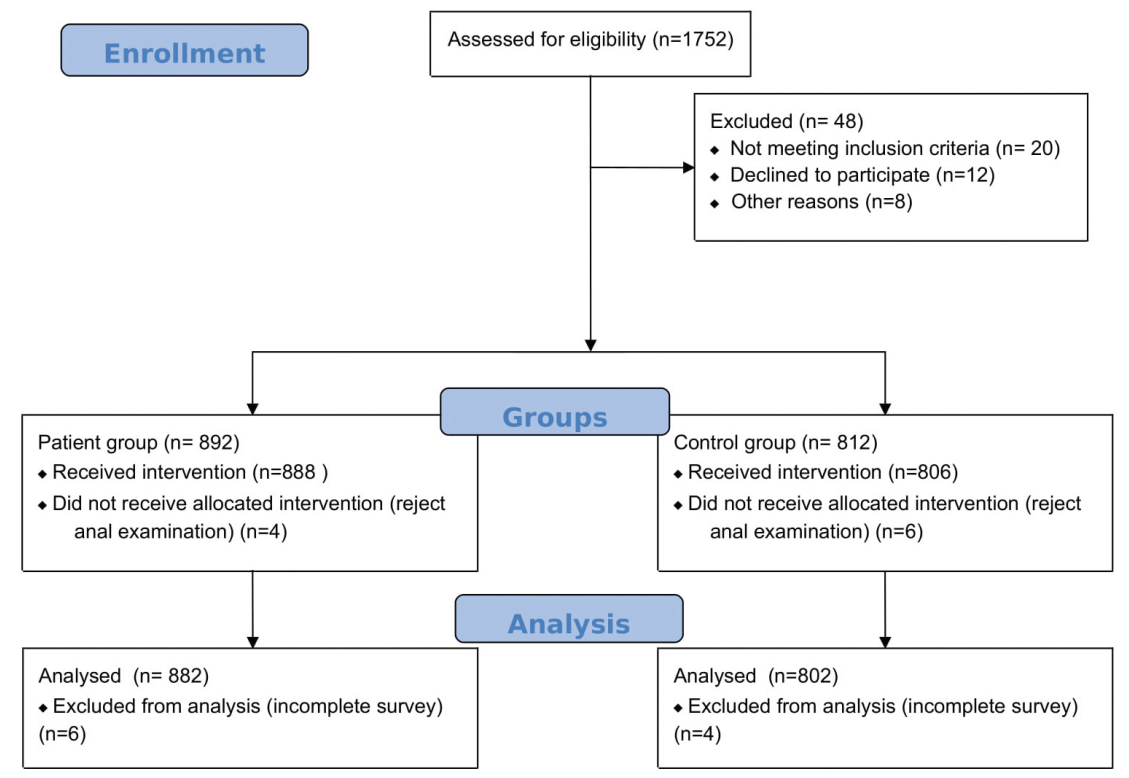

Figure 1. Flow diagram. The number of participants at each stage of the study 
to ensure that the control group came from the same environment and social class as the study group, and in some cases, controls were selected from among close relatives or friends of patients.

Complaints of hemorrhoidal disease, consent to physical examination, and voluntary completion of the questionnaire were the main inclusion criteria. Patients with diseases such as cirrhosis, chronic obstructive pulmonary disease, ascites, or cancer, who refused to be examined or did not complete the questionnaire, were excluded from the study.

Furthermore, the control group had to be healthy and free of any health problems such as hearing or visual disturbances that could be affected by the risk factor (the use of smartphones). The participants in both the patient and control groups ranged in age from 16 to 65 , and both sexes were recruited for the study. Informed consent was obtained from patients and control volunteers, and participants were requested to fill out the Likert-type questionnaire (Table 1). The study was planned so that the doctor performing the proctological examinations would be unaware of the questionnaire results. After the participants completed the questionnaires, the general surgeon examined their anal regions and performed rectal palpations, and the results were added to the questionnaires (Table 1). At the first stage, the presence or absence of hemorrhoids was noted. If hemorrhoids were present, they were classified as either external or internal. Internal hemorrhoids were categorized as stage 1, 2, 3, or 4 based on standard textbook definitions, and the examining physician recorded this information. ${ }^{12}$

\section{Study Size}

Due to a gap in the literature regarding the prevalence of smartphone use in the lavatory, we conducted a pilot study to determine the approximate prevalence and event rate in the population and then calculated the sample size. According to the results of the pilot study, which included 100 patients and 100 controls, $36.4 \%$ of those with hemorrhoidal disease used a smartphone for 2 or more minutes while in the lavatory compared with $13.2 \%$ in the control group. Since our study was a case-control study, we calculated the necessary sample size to determine the prevalence in the patient group using the following formula:

$$
n=\frac{Z^{2} \times \mathrm{p}(1-\mathrm{p})}{d^{2}} \text { and } n=\frac{1.96^{2} \times 0.364(1-0.364)}{0.05^{2}} \text {, then } n=355.7
$$

We chose a target difference (d) of 5\% and assumed a type 1 error of $5 \%$ with a power of $80 \%$. Accordingly, with an event probability of $36.4 \%$, the result obtained was a minimum of 356 patients.

However, because our goal in this study was to investigate the extent to which the use of smartphones (measured in minutes) in the lavatory (independent variable) increases the risk of hemorrhoids, we needed to perform a sample size calculation for binary logistic regression analysis. Based on the results of the pilot study, the rate of smartphone usage in the lavatory for at least 2 minutes was $26.9 \%$ in the whole population. For logistic regression analysis, the formula proposed by Peduzzi et al. ${ }^{13}$ was used:

$$
\mathrm{n}=\frac{10 \times \mathrm{k}}{p}
$$

where $k$ denotes the number of independent variables and $p$ the probability of the event in the general population (the value for $\mathrm{p}$ observed in the pilot study was $26.9 \%$ ). Thus:

$\mathrm{n}=\frac{10 \times 19}{0.269}$, yielding $\mathrm{n}=706.3$

According to these calculations, a minimum of 706 patients and an equal number of controls were required to determine the prevalence of smartphone usage in the lavatory among the patient population (those with hemorrhoidal disease) and to measure the effect of this habit on the development of hemorrhoids. With a $10 \%$ loss due to missing or incorrect data on the questionnaires, we calculated the total number of participants initially necessary for each group (patient and control) to be $706+71=777$.

\section{Statistical Analysis}

All data were analyzed using the statistical software SPSS version 22 (Statistics for Windows, Version 22.0. Armonk, NY, IBM) and Matlab R2015. Frequency and percentage rates were provided for categorical and nominal variables. After continuous numerical variables were checked for normal distribution, those that showed normal distribution were given as mean \pm standard deviation, whereas those that did not were given as median and minimum-maximum values. To identify the variables associated with patient hemorrhoidal status (presence/absence), univariate analysis was performed using the following tests, as appropriate: chi-square, Fisher's exact test, analysis of variance, MannWhitney U, and Kruskal-Wallis. The probability of having hemorrhoidal disease was evaluated using Kernel density estimation (based on Bayesian classifier statistics). For multivariate analysis, the possible factors identified by univariate analysis were entered into logistic regression analysis to determine the independent predictors of patient hemorrhoidal status. The Hosmer-Lemeshow test was applied to assess the goodness of fit of the model. Multiple correspondence analysis was used to analyze the pattern of relationships of several categorical dependent variables. Moreover, a type 1 error level of 5\% was used to determine statistical significance.

\section{Results}

A total of 1752 participants were evaluated for eligibility, with 1684 of them, including 882 (52.4\%) patients and $802(47.6 \%)$ controls, eventually being analyzed (Figure 


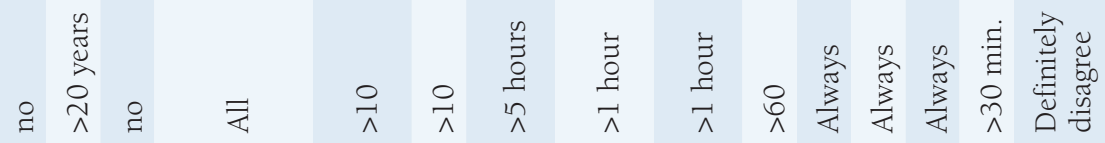

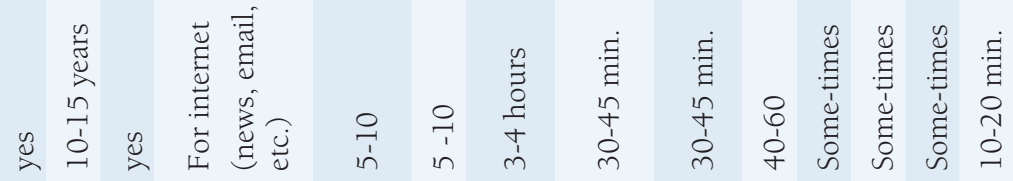

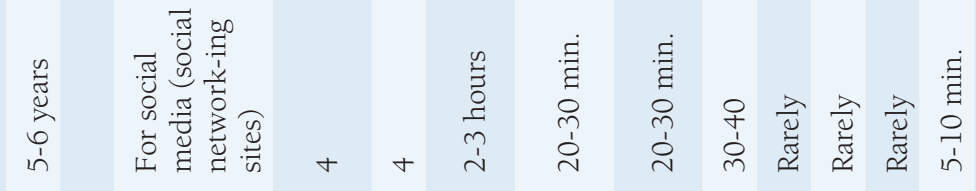

है

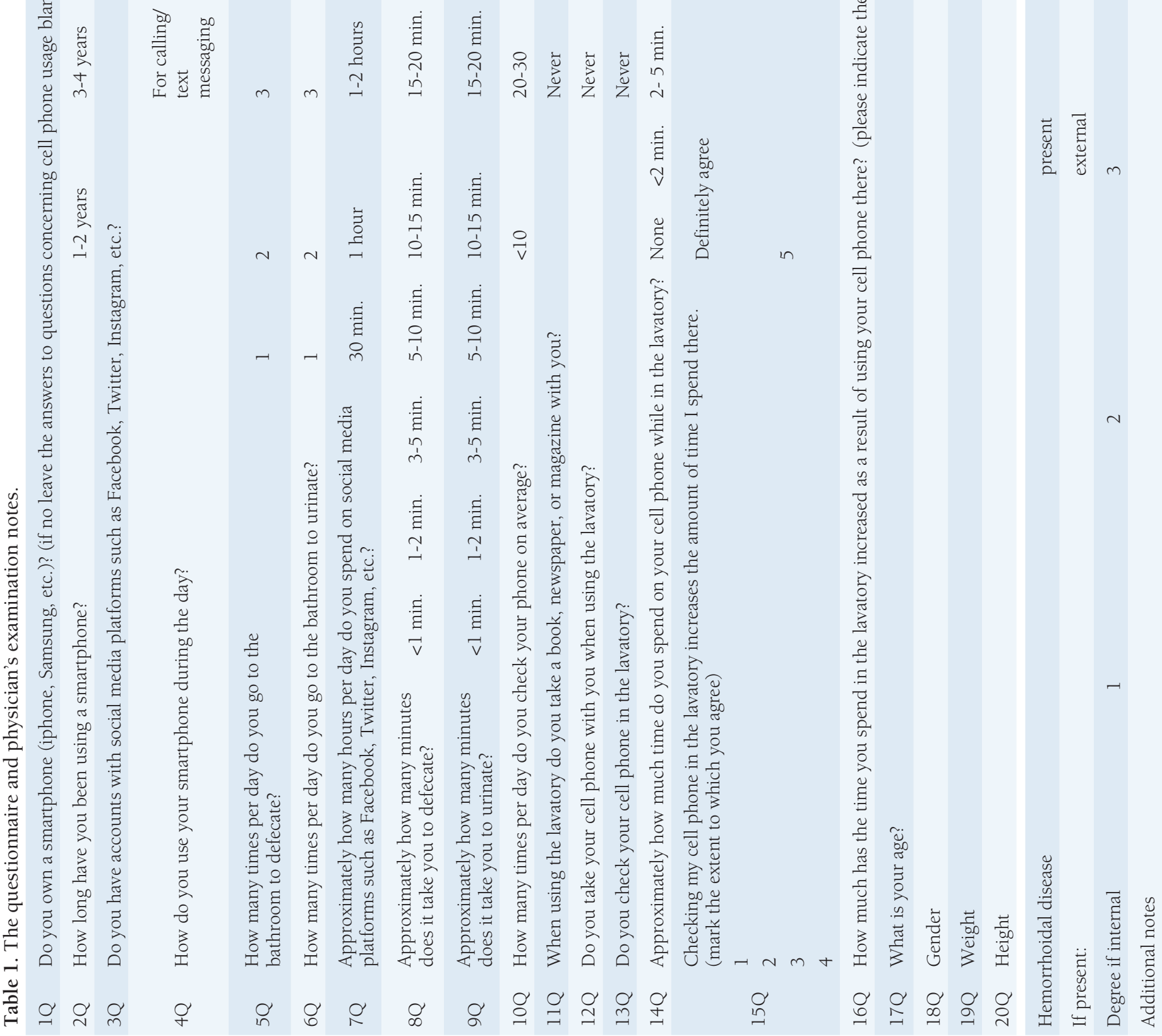


$1)$. The median and mean ages of the study group were 36 (19-64) and $38.1 \pm 10.7$ years, respectively, and those of the control group were 36 (19-57) and $36.08 \pm 8.7$ years $(\mathrm{p}=0.007)$. The patient group included $536(60.8 \%)$ men and $346(39.2 \%)$ women, whereas the control group had $417(52 \%)$ men and 385 (48\%) women $(\mathrm{p}<0.001)$. During the physical examination, all participants in the study group with complaints of hemorrhoidal disease were diagnosed with hemorrhoids, whereas 26 participants in the control group were diagnosed with hemorrhoids despite not having any hemorrhoidal complaints.

Table 2 shows the distributions of responses to questions about the use of smartphones by the patient and control groups. The percentage of the study group that reported taking their smartphones to the lavatory was $64.74 \%$, with $49.9 \%$ actually using them; for the control group, these rates were $38.4 \%$ and $27.3 \%$, respectively.

When the rates at which participants used their smartphones in the lavatory were compared with the development of hemorrhoids, a significant positive association was found $(\mathrm{p}<0.001)$. While 39.7\% (73) participants who reported using their smartphones less than 30 minutes per day were in the patient group, $60.3 \%$ (111) were in the control group. Of those who reported using social media on their smartphones for more than 5 hours per day, 80\% (36) participants were in the patient group and 20\% (9) were in the control group. Regarding the effect of excessive smartphone use on the habit of taking the smartphone to the lavatory, 38.6\% (311) participants who did not report such a habit were in the study group, whereas $61.4 \%$ (494) were in the control group. In contrast, $87 \%$ (141) participants who reported always taking their smartphones to the lavatory were in the study group and only $13 \%$ (21) were in the control group. Figure $2 \mathrm{~A}$ depicts the probability of the disease being present when data from all participants, $47.8 \%$ of whom reported never using their smartphones in the lavatory, was analyzed using Kernel density estimation (Figures 2A and 2B). Because the probabilities of the presence or absence of hemorrhoids are nearly identical, the results presented in Figure $2 \mathrm{~A}$ provide no useful insight. Figure 2B, on the other hand, only shows the data from patients in the study group who took their smartphones to the lavatory (the frequency of which was reported as "rarely," "sometimes," or "always"). In this case, the probability of the presence of the disease (YES) was nearly double that of its absence.

Taking into account the various reasons given for taking the smartphone into the lavatory (such as safety and concern about losing the smartphone), we asked the participants how much time (in minutes) they spent on their smartphones while in the lavatory. Further, $44.4 \%$ of those who did not report using their smartphones in the lavatory were in the study group and $55.6 \%$ were in the control group. A majority (66.4\%) of the participants who used their smartphones in the lavatory for 5-10 minutes were in the study group,

Table 2. Smartphone usage-related survey questions and results by group

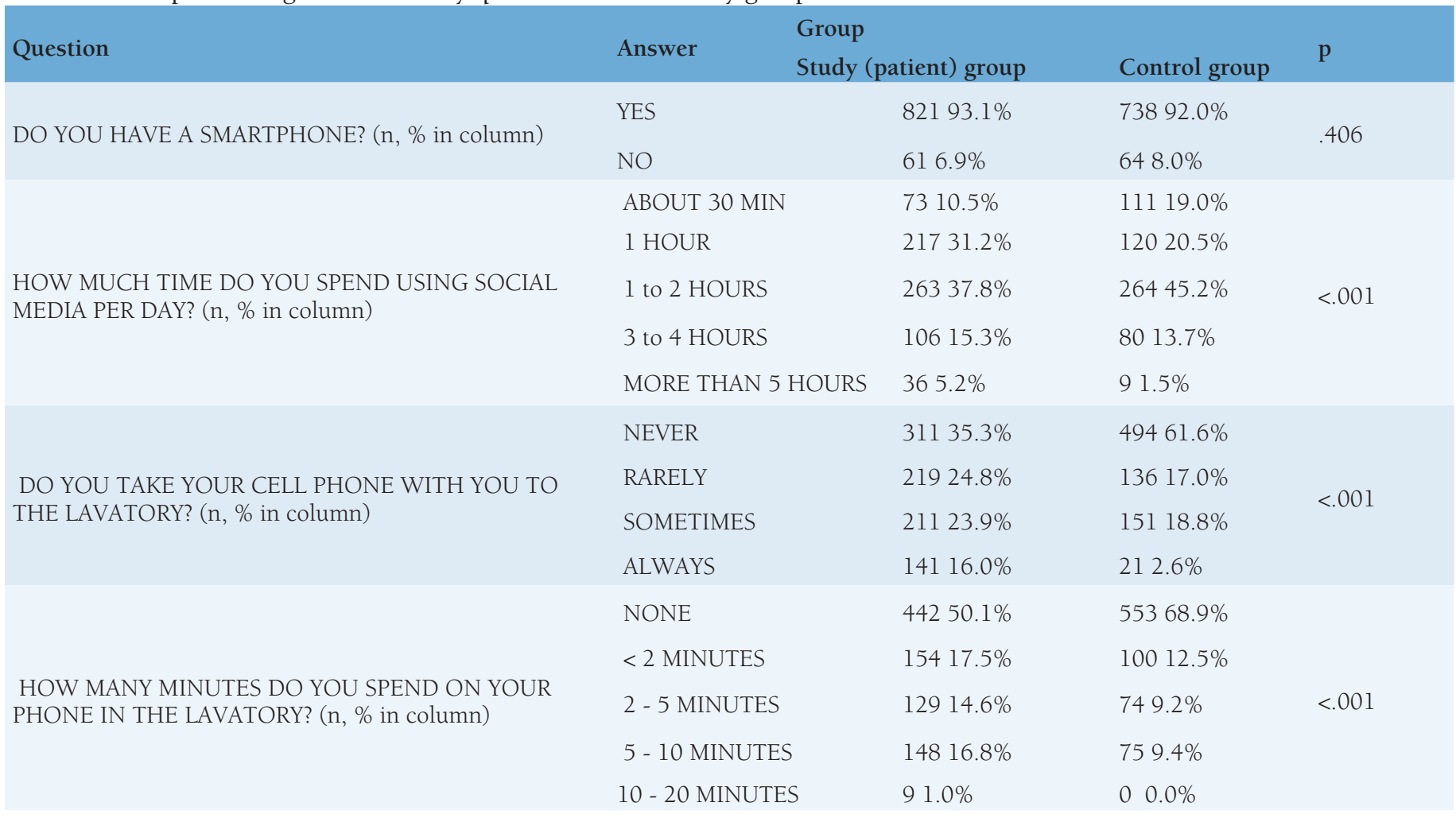


whereas $33.6 \%$ were in the control group, and the rates of those using their smartphones for more than 10 minutes were $100 \%$ and $0 \%$, respectively.

According to the results of logistic regression analysis, the hemorrhoidal disease stage was not observed to be associated with the duration of smartphone use in the lavatory; however, an increase of 1 minute of usage did increase the incidence of hemorrhoidal disease by 1.26 units $(p=0.041$ ). A multidimensional analysis of the basic components of all the data revealed that smartphone use in the lavatory was associated with the development of hemorrhoidal disease (Figure 3). When considering two dimensions together (the right lower quadrant), defecation lasting for more than 10 minutes, use of the smartphone in the lavatory for more than 5 minutes, and "always" taking the smartphone to the lavatory were all associated with a diagnosis of hemorrhoidal disease.

\section{Discussion}

In the present study, we found that the habit of using smartphones in the lavatory resulted indirectly in an increase in the prevalence of hemorrhoidal disease. Although the habit of reading while in the lavatory was thought to be a facilitating factor in the development of hemorrhoidal disease, we were unable to find any clinical studies that supported this finding. To the best of our knowledge, the current study is the first to investigate the relationship between hemorrhoids and reading (books, magazines, or newspapers) or looking at a smartphone while in the lavatory.

With each passing day, technology infiltrates deeper into our daily lives. Naturally, the use of smartphones in the

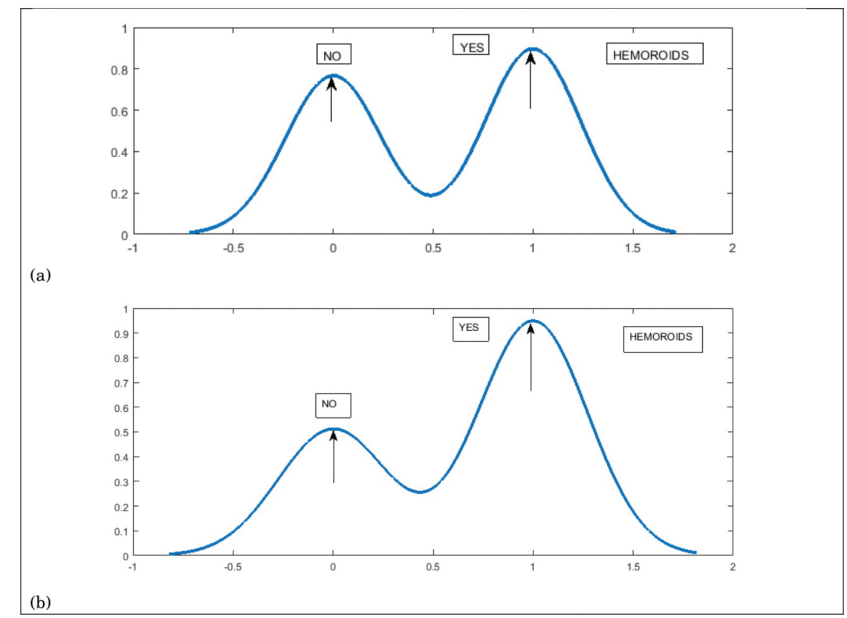

Figure 2. Figure 2A shows the Kernel density estimation of all participants (in both the patient and control groups) who reported taking their smartphones to the lavatory (reported as "rarely," "sometimes," or "always"). Figure 2B shows the Kernel density estimation of only the patients in the study group who reported taking their smartphones to the lavatory (reported as "rarely," "sometimes," or "always") lavatory instead of reading books or magazines, as well as the use of smartphones in the lavatory even by those who were not in the habit of reading books there, has prompted us to investigate the use of smartphones. In recent years, studies have begun to investigate the direct and indirect effects of smartphones on individual and public health. The number of studies on behavioral and psychological changes related to smartphone use, especially among youth, as well as on its effects on public health issues such as depression, is increasing. ${ }^{14}$ On the other hand, smartphone use is thought to have a direct impact on physical health. Frequent use of smartphones has been shown to cause median nerve damage due to excessive movement of the thumb, ultimately leading to impaired movement. ${ }^{15}$ Another negative effect of frequent use is hearing loss. In fact, excessive smartphone use has been shown to cause hearing loss at high frequencies in the ear that is usually used when compared with the other ear. ${ }^{16}$ Another study on the direct effects of excessive smartphone use on the eyes found that using the smartphone more than 4 hours per day affects the ocular surface disease index and causes tear disorders. ${ }^{17}$

As seen from our results, although the age range was 1964 years for both the study and control groups, the median and mean ages were significantly higher for the former. This is also consistent with the fact that hemorrhoidal disease is more common in older people. Although both sexes had equal rates of hemorrhoidal disease, the rates in male and female patients were $60.87 \%$ and $39.2 \%$, respectively, for the study group and $52 \%$ and $48 \%$, respectively, for the control group. As a result, we observed that hemorrhoidal disease is more common in men than in women. However, there is no evidence in the literature to support this conclusion; the disease has been reported to affect both sexes equally. ${ }^{18}$
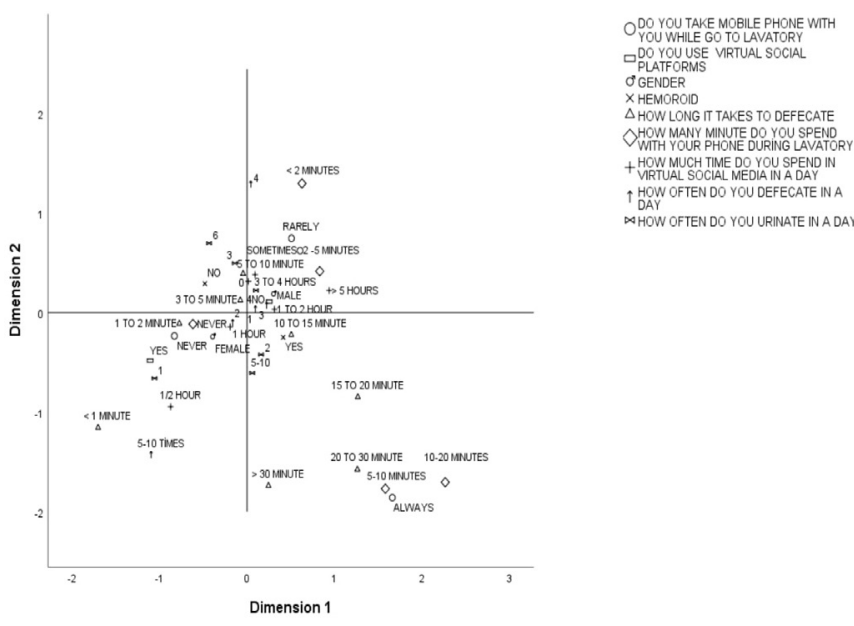

Figure 3. Multidimensional analysis of the basic components thought to be related to the development of hemorrhoids. When both dimensions are taken into account (see the right lower quadrant of the graph), a diagnosis of hemorrhoids (labeled "X") appears to be associated with "always" taking the smartphone to the lavatory, using the smartphone for more than 5 minutes in the lavatory, and defecation lasting more than 10 minutes 
Upon examining the results of the questionnaires, three factors associated with the development of hemorrhoidal disease became apparent. These were the amount of time spent on social media using smartphones during the day, the act of taking the smartphone to the lavatory, and actually using the smartphone while there. Increasing the duration of social media usage on smartphones during the day led to increased use of smartphones in the lavatory, reflecting a kind of dependency. A comparison of the two graphs in Figure 2 shows that people who take their smartphones to the lavatory have a higher risk of developing hemorrhoidal disease.

\section{Study Limitations}

The most important limitation of this study is the potential for bias related to recall, especially since it involves patients' evaluation of their own past habits. Therefore, it is crucial to keep in mind that participants' information about the duration of their smartphone use while in the lavatory may be inaccurate to some extent.

A further limitation is the interobserver variation resulting from the subjective nature of the analysis of hemorrhoids. Although the diagnostic criteria are clearly defined, some variation in the evaluations is inevitable.

\section{Conclusion}

In conclusion, despite its limitations, the present study found a link between the use of smartphones in the lavatory and hemorrhoidal disease as a result of increased use of social media platforms, which was determined to result in longer times spent in the lavatory. Having established that relationship, the question of cause and effect remains. Does using smartphones in the lavatory increase the time spent sitting, naturally resulting in an increase in anal pressure, or is it that individuals with defecation issues, who consequently sit on the toilet for prolonged periods of time, thereby resulting in hemorrhoids, prefer to use their smartphones in the lavatory because they already spend so much time there? To find answers to these questions, we need to carefully conduct further studies using prospectively randomized controlled trials involving healthy adults with no existing signs of hemorrhoidal disease.

\section{Ethics}

Ethics Committee Approval: After receiving approval from the ethics committee of Yeni Yüzyıl University (İstanbul, Turkey), the study was carried out in collaboration with Van Yüzüncü Yıl University (Van, Turkey).

Informed Consent: Informed consent was obtained from patients and control volunteers, and participants were requested to fill out the Likert-type questionnaire (Table 1). Peer-review: Externally and internally peer reviewed.

\section{Authorship Contributions}

Surgical and Medical Practices: E.Z., Concept: E.Z., A.Ö., S.Ç., M.Ç., Design: E.Z., A.Ö., S.Ç., M.Ç., Data Collection or Processing: E.Z., A.Ö., S.Ç., A.S., M.Ç., Analysis or Interpretation: E.Z., S.Ç., A.S., Literature Search: E.Z., S.Ç., M.Ç., Writing: E.Z., M.Ç.

Conflict of Interest: No conflict of interest was declared by the authors.

Financial Disclosure: The authors declared that this study received no financial support.

\section{References}

1. Sun Z, Migaly J. Review of hemorrhoid disease: presentation and management. Clin Colon Rectal Surg 2016;29:22-29.

2. Gecim E. Hemorrhoidal disease. Turk J Colorectal Dis 2011;21:145-159.

3. Johanson JF, Sonnenberg A. Constipation is not a risk factor for hemorrhoids: a case-control study of potential etiological agents. Am J Gastroenterol 1994;89:1981-1986.

4. Gazet JC, Redding W, Rickett JW. The prevalence of haemorrhoids. A preliminary survey. Proc R Soc Med 1970;63(Suppl 1):78-80.

5. Loder PB, Kamm MA, Nicholls RJ, Phillips RK. Haemorrhoids: pathology, pathophysiology and aetiology. Br J Surg 1994;81:946-954.

6. Goenka MK, Kochhar R, Nagi B, Mehta SK. Rectosigmoid varices and other mucosal changes in patients with portal hypertension. Am J Gastroenterol 1991;86:1185-1189.

7. Yoon SO, Park SJ, Yun CH, Chung AS. Roles of matrix metalloproteinases in tumor metastasis and angiogenesis. J Biochem Mol Biol 2003;36:128137.

8. Sun WM, Peck RJ, Shorthouse AJ, Read NW. Haemorrhoids are associated not with hypertrophy of the internal anal sphincter, but with hypertension of the anal cushions. Br J Surg 1992;79:592-594.

9. Ho YH, Seow-Choen F, Goh HS. Haemorrhoidectomy and disordered rectal and anal physiology in patients with prolapsed haemorrhoids. Br J Surg 1995;82:596-598.

10. Gibbons CP, Bannister JJ, Read NW. Role of constipation and anal hypertonia in the pathogenesis of haemorrhoids. Br J Surg 1988;75:656660

11. Ding D, Li J. Smartphone overuse - a growing public health issue. J Psychol Psychother 2017;7:1.

12. Lunniss PJ, Mann CV. Classification of internal haemorrhoids: a discussion paper. Colorectal Dis 2004;6:226-232.

13. Peduzzi P, Concato J, Kemper E, Holford TR, Feinstein AR. A simulation study of the number of events per variable in logistic regression analysis. J Clin Epidemiol 1996;49:1373-1379.

14. Tangmunkongvorakul A, Musumari PM, Thongpibul K, Srithanaviboonchai K, Techasrivichien T, Suguimoto SP, Ono-Kihara M, Kihara M. Association of excessive smartphone use with psychological well-being among university students in Chiang Mai, Thailand. PLoS One 2019;14:e0210294. doi: 10.1371/journal.pone.0210294.

15. Inal EE, DemIrc Ik, CetInturk A, Akgonul M, Savas S. Effects of smartphone overuse on hand function, pinch strength, and the median nerve. Muscle Nerve 2015;52:183-188.

16. Velayutham P, Govindasamy GK, Raman R, Prepageran N, Ng KH. Highfrequency hearing loss among mobile phone users. Indian J Otolaryngol Head Neck Surg 2014;66(Suppl 1):169-172.

17. Choi JH, Li Y, Kim SH, Jin R, Kim YH, Choi W, You IC, Yoon KC. The influences of smartphone use on the status of the tear film and ocular surface. PLoS One 2018;13(10):e0206541. doi: 10.1371/journal. pone.020654l.

18. Sneider EB, Maykel JA. Diagnosis and management of symptomatic hemorrhoids. Surg Clin North Am 2010;90:17-32. 